\title{
Noites comparadas
}

Nlghts compared

\section{Farlley Derze}

Farlley Derze: músico, pós-doutorando em Estética, Hermenêutica e Semiótica, doutor pela FAU/UnB, mestre em Educação Musical pela UnB, professor de História da Iluminação do Instituto de Ensino Superior Brasileiro e Instituto Jamile Tormann. farlley@unb.br

\section{Resumo}

Este estudo é sobre a noite, com o interesse em se verificar como ela foi abordada em diferentes períodos, da Idade Média aos nossos dias. O objetivo foi o de mapear a relação entre a noite e a imaginação. O método adotado foi a comparação das abordagens encontradas na literatura, na música, na pintura e na arquitetura. Nos resultados encontra-se a noite associada a medo, a ritos, a mitos, a poder, mas também à liberdade, à segurança, à beleza, e à modernidade. Concluiu-se que as noites serviram para caracterizar a estética emocional de cada época.

Palavras-chave: Noite. Literatura. Música. Pintura. Arquitetura e cidade.

\section{Abstract}

This study is about the night, with interest in seeing how it was approached in different periods, from the Middle Ages to our days. The goal was to map the relationship between the night and the imagination. The method adopted was the comparison of the approaches found in literature, music, painting and architecture. In the results lies the night associated with fear, rites, myths, power, but also freedom, security, beauty, and modernity. It is concluded that the nights served to characterize the emotional aesthetics of each era.

Keywords: Night. Literature. Music. Paiting. Architecture and city. 


\section{A interpretação da noite}

O que move este texto é a noite. Assim como estamos ligados à mãe, ao pai, aos avós quando somos crianças, estamos ligados à noite aquela que tem um bicho-papão no telhado; aquela que tem a escuridão e o silêncio numa roça; aquela iluminada por postes e lâmpadas elétricas; aquela em que se descansa; aquela em que se sonha; aquela que abriga nossas fantasias. No longo caminho de como a noite fez parte do desenvolvimento cultural, a palavra-chave é a imaginação. Ela encontrou na noite um lar. A noite serviu de combustível não apenas para o surgimento de mitos noturnos, como o bichopapão ou vampiros, mas fornecia faíscas para estimular outras liberdades da imaginação como fizeram os poetas, os músicos, os pintores e os arquitetos. A imaginação provocou também a ciência quando se dedicou a desenvolver meios para iluminar as cidades. Sim, porque alguém teve a ideia de colocar postes nas ruas. Afinal, durante milênios a noite foi uma cópia da escuridão.

A escuridão, todavia, ganhou contornos ora positivos ora negativos. A palavra noite vem do latim Nocte, segundo o nosso dicionário Aurélio, que significa "espaço de tempo em que a luz do sol está abaixo do horizonte" (FERREIRA, 1986, p. 1196). Ainda que em determinados países da Europa o sol venha a se por às $22 \mathrm{~h}$, como no verão, na média restam oito horas noturnas. Oito horas sem luz, oito horas como a negação do dia: noite (não-oito), nuit (non-huit), night (no-eight), nacht (nein-acht), noche (nonocho)... Se a noite não está livre de conotar-se como a negação da luz, imagine-se como isso foi tratado nas mitologias religiosas, em que almas iluminadas são diferentes dos seres das trevas. Daí em diante a população que estiver colonizada sob tais parâmetros míticos, se verá perante a luta do bem contra o mal. Quem tiver a luz, quem viver no paraíso iluminado, quem receber uma "iluminação" (como disse Santo Agostinho em sua obra "Confissões") terá recebido um dom, um tipo de poder.

Curiosamente, essa herança psicológica do poder da luz sobre as trevas é visível em manifestações do nosso cotidiano. Na comemoração de um aniversário, na hora de se cantar os parabéns, apagam-se as luzes e o aniversariante, apenas ele, tem à sua frente a luz que simboliza sua vida, o poder de ter sobrevivido mais um ano; à zero hora do dia primeiro de janeiro, os ceús do mundo inteiro ganham luzes que se impõem sob o manto escuro para se comemorar a vi(n)da de um novo ano; no passado, os casamentos eram realizados à noite, os funerais (velórios...velas) também. Afinal, o defunto partiu daqui para uma melhor. $\mathrm{O}$ que dizer das luzes na comemoração do Natal, pelo nascimento da divindade cristã? $\mathrm{E}$ as procissões realizadas à noite em que os fiéis caminham com velas acesas na mão? Conclui-se que, durante a noite (num espaço escuro), é mais evidente a ação (o poder) do homem sobre a escuridão. Assim fomos simbolicamente alfabetizados.

Abro um parênteses para que o leitor decida como interpretar uma coincidência ou um legado deixado (ou criado) por diferentes culturas em que o homem teve privilégios sobre a mulher, para comandar igrejas, comandar quartéis, comandar o senado, comandar tribunais da Inquisição (e outros). O dia, onde há luz, é substantivo masculino; a noite, sem luz, é substantivo feminino. Fecho parênteses.

A noite, por motivos religiosos (portanto, psicológicos), converteu-se no simulacro das trevas e, por causa disso, fomos habituados pouco a pouco a compreender o valor da luta por uma vida mais espiritual, rumo ao paraíso iluminado. Toda alma (e toda cidade) que queira vencer não poderá abrir mão de ter a luz ao seu redor. Não à toa, governantes buscaram iluminar templos e palácios com a luz artificial e, quanto mais luz espalhavam, mais impunham algum tipo de soberania ao mesmo tempo que construíam novos paradigmas sobre a cidade à noite. Um deles: o embelezamento. Todavia, cuidado: beleza também representar poder! Uma passagem da biografia de Cleópatra se refere ao luxo que havia em seu palácio quando convidava lideranças romanas para uma festa: "o que mais surpreendeu foi a quantidade de archotes que iluminavam por todos os lados, uns suspensos no teto, outros presos às paredes" (p. 37). Segundo um de seus biógrafos, as grandiosas cerimônias e encenações eram destinadas a "impressionar a imaginação popular" como forma de sustentar sua credibilidade como monarca.

Quando escrevi o final do parágrafo anterior, imaginei nossos ancestrais nas cavernas quando lutavam para dominar o fogo, confinados em sua humildade histórica. Não sabiam que a luz seria um símbolo de poder que estetizaria edificações (catedrais, palácios, etc.) e vias urbanas de cidades que deram uma mensagem ao mundo sobre seu poder econômico e político (Paris, Londres, Tóquio, Las Vegas, Nova York, Xangai...). 


\section{Luz é poder}

As cidades se desenvolvem como um corpo de pedra. Nada que uma guerra não destrua a ponto de se ver cidades queimadas, bombardeadas e feridas. Se ninguém quer uma alma ferida, ninguém quer também uma cidade ferida. É preciso que além das almas, as cidades sejam iluminadas. Fiat lux.

A luz quebra a fronteira da escuridão ao mesmo tempo que se impõe como força, a força do homem sobre a natureza.

Para que tivéssemos as noites com experimentamos hoje - iluminadas - alguém precisou dar o primeiro passo. Entra em cena, no século XVII, um rei francês, Luís XIV. Reis disputavam territórios e a cada conquista, havia o reconhecimento de poder. Ele vai ser o primeiro monarca europeu a converter a cidade de Paris num espetáculo de poder - o poder sobre a noite. As ruas serão iluminadas numa escala jamais vista num espaço urbano. Gostava de ser chamado de "ReiSol". Paris será conhecida como la ville lumière. Se a NASA existisse naquela época estaria fotografando nosso planeta às escuras, exceto pela presença de um foco de luz brilhante lá embaixo, como se fosse uma pérola a reluzir dentro de um globo escuro.

Obviamente, as áreas iluminadas não eram as áreas onde viviam os pobres. Estes permaneceriam à mercê do medo da noite (das trevas) enquanto a monarquia e o clero concentravam a luz sobre si. O que se ilumina com a luz artificial são monumentos, estátuas, fachadas palacianas e tudo aquilo que se quer valorizar para a história que, no final das contas, éa história do poder. Só mais tarde, os burgueses, os bancos, o comércio... estariam em condições de mostrar ao mundo suas luzes.

No filme que trata da biografia de Mozart, ambientado no século XVIII, há uma cena em que uma cantora interpreta uma ópera do compositor, regida pelo próprio, no interior de um teatro completamente iluminado por candelabros suspensos, à luz de velas. Ora, bastava que a ópera ocorresse após o almoço ou antes do por-do-sol. Porém, à noite ocorre a oportunidade de se envolver as pessoas num "mundo mágico", criar uma atmosfera de "mistério e luxo", com centenas de velas acesas a brilhar sobre os candelabros e situá-las no universo do poder.

Um parênteses. Na época de Mozart as velas eram feitas da gordura da baleia, que forneciam uma luz muito brilhante e liberavam pouca fumaça. Somente os ricos usavam velas. Os pobres não poderiam admitir comprar um artefato que dava luz apenas por três horas (se fosse uma vela de 15 centímetros na espessura de um dedo). Ademais, os pobres não aceitariam comprar a luz de um artefato que derretia e custava caro. Era caro porque era esteticamente mais atraente do que as lamparinas de barro que os pobres usavam desde seus tataravós. Cada lamparina tinha um pavio mergulhado na gordura derretida que sobravam dos animais que também lhes serviam de alimento. Fecho o parênteses.

De Cleópatra a Luís XIV, de Mozart aos shows da Madonna ou do Roberto Carlos, a luz valoriza a distância (ou a diferença) que existe entre seres com muito ou pouco poder. Pensemos também no poder territorial ou no poder espiritual, com consequências sobre a estética emocional de cada época, em que não se perde de vista a luta entre o medo e o interesse pela liberdade.

E por falar em liberdade, poetas, músicos e pintores souberam enxergar a noite como um espaço rico para a liberdade, não apenas a sensualidade presente nos livros, nas canções ou pinturas, mas a liberdade para a troca de ideias, o encontro noturno nos cafés para estimular uma imaginação menos religiosa e mais humana. "A cidade mostra sua verdadeira face à noite" (TROTSKY).

\section{As cartas na mesa}

A ideia é realizar comparações sobre como as noites foram interpretadas em diferentes épocas pela literatura, música, pintura e arquitetura contemporânea. Usar a comparação como método tem menos a ver com uma prática acadêmica e mais com minha herança cultural. Faço parte de uma cultura que se acostumou a comparar, inclusive, sua grama com a do vizinho. Aliás, ninguém precisa fazer parte do meio acadêmico ou receber um diploma de pós-graduação por fazer comparações já que a comparação é culturalmente ensinada desde quando se nasce. Compara-se o bem e o mal, o certo e o errado, o feio e o bonito, o quarto rosa e o quarto azul, o velho e o novo, a realidade e a fantasia e a lista parece não ter fim. Todavia, por ter escolhido produzir um texto para um público-alvo de acadêmicos, bem-dizer o primeiro público que terá contato com este trabalho, adoto aqui a preocupação de elucidar a maneira como realizei a tarefa. $E$ faz parte da tarefa ouvir os mais experientes: " $A$ comparação não deve ser ocasional nem ao acaso. [...] É preciso haver elementos de identidade entre 
os membros para que se destaquem as diferenças, que, por sua vez, caracterizam mais a identidade diferenciada de cada membro" (KOTHE, 2016, p. 633). Com essa bússola na mão, idealizei os seguintes passos: 1 - apresentar uma ideia; 2 - usar três tipos de fontes para a extração de dados que possam contextualizar tal ideia: fontes textuais (textos em geral), fontes musicais (títulos de músicas), fontes visuais (a fotografia e a pintura; nestas estão embutidas as imagens de cidades e edificações); 3 determinar o foco: buscar nas fontes toda alusão feita à palavra noite; 4 - uma vez localizada a palavra noite ou uma imagem noturna, analisar o contexto que the cerca a fim de extrair uma conclusão sobre como as noites foram abordadas; 5 - cada tipo de abordagem fará parte de um sistema de classificação associada à noite: o medo, a segurança, a liberdade, a economia, a beleza, o poder, o descanso, a contemplação, a escuridão (ou trevas), a morte, a iluminação artificial (as tecnologias), a luz da lua, lutas, mitos, ritos, o silêncio, o entretenimento, o trabalho e a modernidade; 6 - apresentar no presente texto apenas alguns dados, por razões de limitação de espaço e prazo para a publicação: algumas citações sobre a noite encontradas na literatura, alguns títulos de composições musicais alusivas à noite e algumas pinturas que evocam a noite; 7 apresentar no decorrer do texto algumas linhas argumentativas que possam convergir para a ideia central a ser defendida: as noites serviram para caracterizar a estética emocional de cada época. Portanto, a ideia central é ao mesmo tempo a conclusão do trabalho.

Sob o ponto de vista da argumentação, quero andar de mãos dadas com Aristóteles. Ou seja, dizer que Aé causa de B. O sociólogo norte-americano Howard Becker demonstra-se incomodado diante da "incapacidade ou falta de vontade dos cientistas sociais de fazer afirmativas causais" (BECKER, 2015, p. 34). Eu não sou um cientista social, mas admiro aqueles que se arriscam como fez Durkheim ao afirmar que o suicídio tinha uma causa. Um acadêmico ao escrever pode (e deve) ser cobrado por aquilo que seu texto afirma. Becker considera os textos dos cientistas sociais ruins (ele generaliza com base naquilo que leu na cultura acadêmica das ciências sociais em nossa época do politicamente correto) porque seus pares sabem que "correrão sérios riscos acadêmicos se alegarem que A é causa de B" (p. 15). Seriam textos que ficam em cima do muro. Assim, tenho interesse (tão antigo quanto o de Aristóteles) em alegar que A é causa de B. Este texto pode cair num lado ou noutro dos inúmeros muros acadêmicos, aqueles que separam os departamentos e as áreas (humanas, exatas, etc.). Pode cair no lado onde há mandíbulas que o farejem para em seguida destroçarem parágrafos ou páginas inteiras porque não concordam que Aé causa de B; pode cair no lado em que seja mergulhado num balde de ácidos porque consideram a causa abstrata, como se a filosofia, a abstração e a imaginação não dessem corda no mundo. De todo modo, eis aqui um trabalho que afirma alguma coisa a partir de outra coisa.

A primeira coisa é a noite, esta entidade natural que funciona como uma aparição do conceito de tempo. E a afirmação que lhes apresento é esta: as noites serviram para caracterizar a estética emocional de cada época. Falo noites no plural porque a noite italiana de Galileu Galilei é diferente da noite novaiorquina de Wood Allen. A noite de nossos bisavós eram diferentes das noites que hoje experimentamos. Talvez, tenhamos todos algo em comum, aqueles que já morreram e os que lêem esse texto: uma dívida emotiva com a noite. Seja a emoção do medo do bicho-papão no telhado, ou a de uma noite de núpcias, ou a emoção dos astrônomos, dos cabarés, das festas de 15 anos de uma jovem debutante... Em síntese, a noite é causa (é fonte) de estéticas emocionais. Quando pensei nisso, me pareceu óbvio (e simplório). Então eu quis usar a imaginação para voltar no tempo. Eu não posso viajar no tempo a ponto de me encontrar com Joana D'Arc, mas há livros sobre ela e, portanto, relatos sobre a Idade Média e não é novidade que naquela época não havia postes nas ruas e, por isso, a circulação nas ruas durante a noite era proibida por decreto (que vigorou até o século XVIII). O medo era a estética emocional que predominava naquele período. Todavia, noutra parte deste trabalho vou defender que a noite não é a causa (não é a fonte) do medo.

Mas não é hora ainda de trabalhar na argumentação. Nesta seção quis apresentar o método de trabalho. Por exemplo, quando tenho uma fonte textual na mão (um livro sobre Jack, o estripador) meus olhos buscam a palavra "noite". Faz parte do método classificar o contexto em que a palavra noite está associada. Nem preciso dizer o que o tal Jack fez em Londres entre agosto e novembro de 1888 . Ou melhor, nem preciso dizer em que momento ele agia contra suas vítimas. O livro tem 13 capítulos e a palavra noite é citada 147 vezes. Isso dá uma média aproximada de 11 citações por capítulo. Em algumas passagens a palavra noite está associada a descanso; noutras a sexo; noutras a medo; noutras à morte. Já no livro As mil e uma noites, traduzida por Mansur Chalita, a palavra noite é citada 362 vezes, a começar pelo título: noite associada ao medo, à liberdade, ao sexo, à bruxaria, etc. Com outros 
textos no colo, percebi que a palavra noite associada à economia ou entretenimento não aparece na Idade Média, mas aparece quando a indústria, o comércio, o teatro passam a funcionar à noite. A noite associada a poder, aparece na biografia de Cleópatra e Luís XIV. Basicamente, o método consiste em compilar a palavra noite na literatura, na música, na pintura e na arquitetura, classificar o contexto em que está associada e utilizar o material para fundamentar a afirmação de que as noites serviram para caracterizar a estética emocional de cada época.

"A leitura de uma obra deve basear-se na análise, mas não pode reduzir-se ao exame da técnica formal, nem olvidar o passo para a síntese" (KOTHE, 2016, p. 240). Trabalho com a ideia de noite como obra uma obra que ultrapassou sua condição natural e adquiriu contornos de uma escultura confeccionada a muitas mãos. A escultura da noite. Acredito que existem variações na intensidade simbólica da noite (da imagem noturna, do espaço noturno, do tempo noturno). Variações que proponho serem detectadas na literatura, na música, na pintura e na arquitetura.

O trabalho que ora exponho é um começo. E por ter um enorme prazer com esta pesquisa, não faço ideia de quando poderei dizer que está concluído (duvido que seja possível). Por fim, para encerrar esta seção, espero que até meados de 2019 eu possa disponibilizar mais dados para iluminar o trajeto da argumentação. Realizo este trabalho como quem escreve sob a luz de velas uma biografia da noite. Ouço-a na literatura, na música, na pintura, na cidade.

\section{Diferenças aqui e acolá}

Qual a diferença entre a noite paleolítica e a noite citadina? Ambas são escuras, ambas são trevas. Todavia, será na cidade que a noite ganhará seu algoz mítico, quando sua escuridão (natural) for povoada por seres (artificiais e sobrenaturais). Mas de quais cidades escuras se está falando? A cidade em que vivia Cleópatra, Platão, Cristo, Galileu, Kant, Freud, Thomas Edison? Quando a noite passou a ser ameaçadora? Arrisco-me a dizer que a noite intramuros, isto é, a noite contida na cidade passou a ser alvo de especulação mítica por aqueles que conseguiram um lugar de destaque na organização política e social. Enquanto reis e imperadores se preocupavam com a defesa de seus territórios, a igreja tomou para si a responsabilidade de se preocupar com os territórios metafísicos: o paraíso (iluminado) e o inferno - mundo das trevas - cuja única luz vem de uma fogueira. A igreja passa a controlar os territórios do futuro, onde se mora após a morte. Ela dará o carimbo no passaporte das pessoas boas ou más, segundo a lógica mítica e política que ela mesmo organizou. Aponto as lentes para a igreja cristã medieval, embora ainda hoje muitos humanos levem seus filhos para o batismo de modo que a família tenha o passaporte para uma eternidade iluminada, porque ninguém quer viver o futuro na cidade do diabo ou na república do inferno. Em outras palavras, o que começou na Idade Média como um certo tipo de escravidão (mental), perdura até hoje nas mentes mais dependentes do futuro.

\section{Antes da Idade Média}

No livro $\boldsymbol{A}$ política, escrito por Aristóteles, enquanto buscava a palavra noite, encontrei as palavras "cidade" e "escravidão". Aristóteles disse que a escravidão só acontece "pela lei do mais forte". Aqui a gente pode fazer um link com o poder do mais forte no futuro próximo de Aristóteles, o ambiente medieval.

A igreja cristã, que desde suas origens até a Inquisição lutaram pelo monopólio das almas; as que não aceitassem a domesticação dentro dos moldes pedagógicos da época, eram almas difíceis de se escravizar e, portanto, não poderiam contaminar o paraíso. $O$ destino de aproximadamente quinhentas mil almas - ou melhor, seres humanos - ao longo da inquisição europeia, já sabemos qual foi. Dizem que onde há fumaça há fogo. Ou, onde há escravidão há cidade. Em hipótese alguma quero imputar culpa à cidade pelos mandos e desmandos sobre o destino de quem nela vive. O problema está, como sempre, no poder. Aristóteles menciona ações dos "tiranos" de sua época. A palavra noite é citada duas vezes nas 224 páginas da obra (na edição que tenho em mãos). $\mathrm{Na}$ primeira vez refere-se ao uso de patrulhas noturnas "para impedir que os habitantes não se conheçam entre si, já que as relações só servem para torná-los mais confiantes". Vejamos a próxima citação: "Eu acredito que, se tivéssemos que passar uma mensagem, seria a de que é melhor povoar a noite do que controlar a noite". Desculpe, esta citação não é de Aristóteles, mas do geógrafo francês Luc Gwiazdzinski, quando em 2014 veio a São Paulo para participar de um evento chamado "Manifesto da noite - em busca de uma cidadania $24 \mathrm{~h}$ ", promovido pelo grupo multidisciplinar COLABORATÓRIO. Só citei porque combina com a primeira citação, a de Aristóteles. Na segunda citação de nosso filósofo grego a noite está associada à expressão "prazeres sensuais". O livro trata da política e da cidade, a palavra noite foi citada 
duas vezes e nenhum monstro mítico foi citado, nenhum dragão, nenhum vampiro, nenhum tipo de demônio ou bruxa.

Seja no mundo de Aristóteles, seja nos dias atuais, o ponto central que busco defender é que o medo da noite é consequência das histórias mitológicas (cristãs ou não), ou da presença de invasores ou ladrões nas cidades que possuem alguma riqueza espacial (território) e material (ouro, dinheiro, etc.). Basta ver que no sertão da Bahia ou da Paraíba, ou nas montanhas de Tuva na Mongólia as noites permanecem quietas e sadias.

\section{O legado noturno da Idade Média}

A recorrência de palavras como "trevas", "medo", "feitiçarias", "macabro", "demônio", "sombras" dentre outras impregnaram o mundo noturno natural. Se a igreja cristã não tiver nada a ver com essa espécie de "roubo da noite", quero dizer, da paz e do silêncio de sua natureza quando associaram sua escuridão a seus produtos metafísicos (trevas, demônios, etc.), no mínimo se merece uma explicação do porquê de, grosso modo, a igreja medieval ter investido tanto na ideia da existência de um mundo das trevas; mundo este visto como o destino daqueles que não se iluminaram espiritualmente, isto é, dentro dos padrões canônicos da pedagogia social medieval.

Com a graça das divindades, da cavalaria e dos corajosos de cada família, a cidade à noite teria que ficar protegida, cercada por muros e com portões vigiados. Pois nem só de medo do bicho papão no telhado viverá o homem, mas também das invasões. Estou tentando dizer que esse espectro mítico, como diria o professor Fernando Fuão, permeia a realidade citadina, mas em defesa da noite prefiro desvinculála desse parâmetro emocional, porque se uma cidade precisa se resguardar com exércitos e muros, não é por causa da noite, mas por algum tipo de riqueza acumulada ali. Do contrário, seria preciso colocar muros em todo o planeta terra, inclusive no sertão da Paraíba ou da Bahia, ou nos pampas gaúchos, ou nas roças de Goiânia e Minas Gerais, onde quer que as noites caiam. Ou seja, a noite não tem nada a ver com o perigo, mas foi roubada para ganhar uma máscara e ser lançada de volta nas ruas como a portadora de uma doença chamada trevas. Os muros emocionais foram erguidos para através da comoção do medo se atingir a libertação da alma. Já os muros físicos, de pedras, ao redor das cidades, passo a palavra a Richard
Sennet, professor da London School of Economics: "as cidades gregas tinham muralhas de proteção [...] erguida talvez mil anos antes de Péricles" (1994, p. 34), que era o general ateniense do século V a.C. Portanto, os muros não poderiam existir porque as noites eram perigosas ou habitadas por seres sobrenaturais, mas porque as cidades tinham atrativos para os forasteiros de plantão. Todavia, como proponho aqui, a ideia de um mundo das trevas que circulava de modo insistente na Idade Média criou também muros contra a liberdade da percepção do mundo. Platão já tinha deixado um legado com sua alegoria da caverna e deve ter proposto tal reflexão na melhor das intenções, qual seja, a de despertar a consciência sobre um mundo fora da própria cabeça - a cabeça é a caverna, é a coisa escura onde residem sombras do conhecimento e as ideias às quais uma pessoa se acostumou a admirare repetir. É lá fora (fora da cabeça), no contato com o outro (com a cabeça do outro), com o diferente, ou com os livros antes de serem queimados, que há um mundo repleto de experiências que desafiam a verdade de cada um, a crença particular de cada um. Estava lançada a pedra fundamental para uma dicotomia entre luz e escuridão.

No caso medieval, a questão ganhará forma e força espiritual. Passo a palavra a Sennet mais uma vez: "qualquer sociedade precisa de fortes sanções morais para impor tolerância à dualidade, ao incompleto e ao outro. Na cultura ocidental, essas medidas repressivas emanaram dos poderes da religião" (p. 378).

Esticando os olhos até o Oriente, chama a atenção o modo com havia mil e uma noites, inclusive noites de sexo. De volta ao Ocidente, a Idade Média pregava que "Deus é luz", mas ironicamente ficará conhecida como "Idade das Trevas". Sabemos que, essa ironia associa o termo "trevas" à "ausência da razão", por exemplo, para explicar os fenômenos naturais do mundo. Quem ousasse oferecer explicações mais iluminadas (razoáveis, racionais, com raiz no intelecto) do que o cânone da cristandade, carimbava o passaporte para a fogueira. No final das contas, espiar a noite com lentes telescópicas poderia ameaçar as pseudorepresentações da hierarquia mítica que se apoiava no valor negativo das trevas. Copérnico, Galileu e cientistas da astronomia devolveriam à noite sua serenidade cósmica.

Enquanto cientistas trabalhavam às escondidas, a Idade Média lutava para multiplicar a ideia de trevas como abrigo de demônios e bruxas. Até animais como corujas e gatos negros, eram entendidos como sócios das bruxas e dos feiticeiros. Quem leu O grande 
massacre dos gatos (1986) do antropólogo, e professor de história da Princenton University, Robert Darnton, vai se lembrar que ele faz um estudo sobre categorias de realidades e nos alerta que os significados vão ser inscritos conforme determinada visão de mundo, inclusive a visão de que era necessário exterminar todos os gatos (e só não exterminaram as corujas porque estas sabem voar), de modo que não tardou se ver uma Europa medieval assolada por uma peste...adivinhem o sobrenome: peste negra!

Como estou de olho na palavra noite, já entendi que ela recebeu conotações - escuridão, trevas, negra - que é o contrário de um dia ensolarado e, por isso, ronda na literatura mítica a associação entre o perigo e a escuridão. A mitologia cristã obteve sucesso em universalizar seus motivos para assegurar sua hierarquia na cidadela, tanto na terra como no céu. No vocabulário emotivo, nada melhor para as lideranças religiosas do período do que falar em trevas e iluminação, que no fim das contas alavancou sua economia e sua posição social, pois passou a ser vista como instituição necessária nas cidades europeias e, mais tarde, impôs-se também naquelas que foram colonizadas nas Américas e na África com o auxílio de chicotes e gatilhos.

Como no final do Novo Testamento, no livro de Apocalipse, a morte está acompanhada pelo julgamento, pelo juízo final, não aquele juízo crítico kantiano, mas aquele com sementes medievais, pinturas europeias que vão explorar em suas composições o contraste entre o desespero ou a incerteza na escuridão (a noite) e o poder de quem é ou está iluminado. No dia do juízo final, aqueles que mantiveram sua devoção teórica aos ensinamentos terão um lugar ao sol.

\section{Um passeio pela noite na literatura}

\section{Palavra-chave: poder}

Livro: Vento noturno (Charles Dickens); recorte temporal: séc. XIX até meados do séc. XX; nos permite interpretar que o vento noturno tem mais poder que o vento diurno.

"Porque o vento noturno tem o capricho sinistro de vaguear e voltear ao redor de um edifício dessa espécie, gemendo lamentos, enquanto passa; de forçar, com as suas mãos invisíveis, as janelas e as portas; e de procurar algumas frestas, por onde penetrar. E quando consegue entrar, ele, como alguém que não encontra o que procura, seja lá o que for que busque, chora e uiva" (DICKENS, 1975, p. 17).

\section{Palavra-chave: medo}

Livro: O último herói (Rick Riordan); recorte temporal: séc. XX.

“... se eu realmente acreditasse no País dos Fantasmas, em espíritos de animais ou em deuses gregos... acho que não conseguiria dormir à noite (RIORDAN, 2011, p. 93).

Livro: Pedro Páramo (Juan Rulfo); recorte temporal: séc. XX.

"Porque tinha medo das noites que enchiam a escuridão de fantasmas" (RULFO, 2008, p. 137).

Livro: Night; (Alfred Alvarez); recorte temporal: Idade Média.

"A noite por muito tempo foi o momento do medo de predadores ocultos na escuridão, e porque os homens estavam mais vulneráveis durante o sono" (ALVAREZ, 1994:132).

Livro: O viajante noturno (B. Traven); recorte temporal: séc. XIX até meados do séc. XX.

"Eu teria medo de entrar num quarto escuro ou dormir com as luzes apagadas" (TRAVEN, 2008, p. 55).

\section{Palavra-chave: beleza}

Livro: O viajante noturno (B. Traven); recorte temporal: séc. XIX até meados do séc. XX.

"Meia-noite. Uma noite bela e clara, pelo que sei. Todas as estrelas brilham como diamantes" (TRAVEN, 2008, p. 79). 
Livro: O campo e a cidade (Reymond Williams); recorte temporal: séc. XIX até meados do séc. XX.

"Desde o início do século XIX a iluminação a gás era usada tanto para fazer efeito e impressionar quanto para realmente iluminar, e muitos habitantes e visitantes tinham a mesma impressão" (WILLIAMS, 2011:374).

\section{Palavra-chave: descanso}

Livro: O viajante noturno (B. Traven); recorte temporal: séc. XIX até meados do séc. XX.

"Boa noite. Vou me deitar" (TRAVEN, 2008, p. 75). "Fazia semanas que eu não dormia tão bem como naquela noite" (p. 69).

Livro: Escuridão total sem estrelas (Stephen King); recorte temporal: séc. XX.

“...e eu pensei que nós dois precisávamos de uma noite decente de sono" (KING, 2015, p. 34).

\section{Palavra-chave: iluminação artificial/tecnologias}

Livro: O viajante noturno; recorte temporal: séc. XIX até meados do séc. XX.

"Todo santo dia, eu lia do amanhecer até a meia-noite. A luz de que dispunha era a de um simples candeeiro de cozinha, que iluminava parcamente". (TRAVEN, 2008, p. 32). "A sensação de estar vivendo no passado era ainda mais forte à noite, quando eu lia à fraca luz do candeeiro” p. 40).

Livro: O campo e a cidade (Reymond Williams); recorte temporal: séc. XIX até meados do séc. XX.

"Desde o início do século XIX a iluminação a gás era usada tanto para fazer efeito e impressionar quanto para realmente iluminar, e muitos habitantes e visitantes tinham a mesma impressão" (WILLIAMS, 2011:374).

Livro: Escuridão total sem estrelas (Stephen King); recorte temporal: séc. XX.

"Havia uma lâmpada de arco voltaico pendurada em um gancho à direita da porta [...]. Procurei o botão de ligar e o apertei. Um círculo brilhante de luz azul e branca surgiu” (KING, 2015, p. 38).

\section{Clair de lune}

Claude Debussy

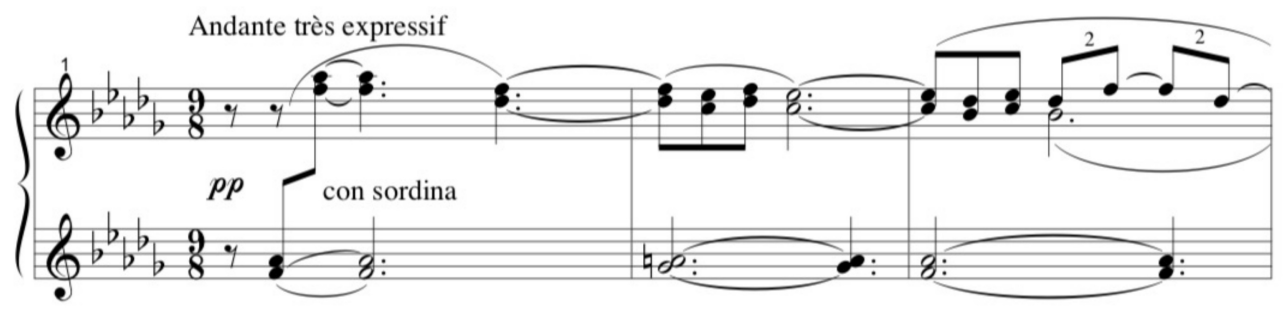

Figura 1

Partitura: Clair de lune (Claude

Debussy, 1905).

Fonte: arquivo pessoal.

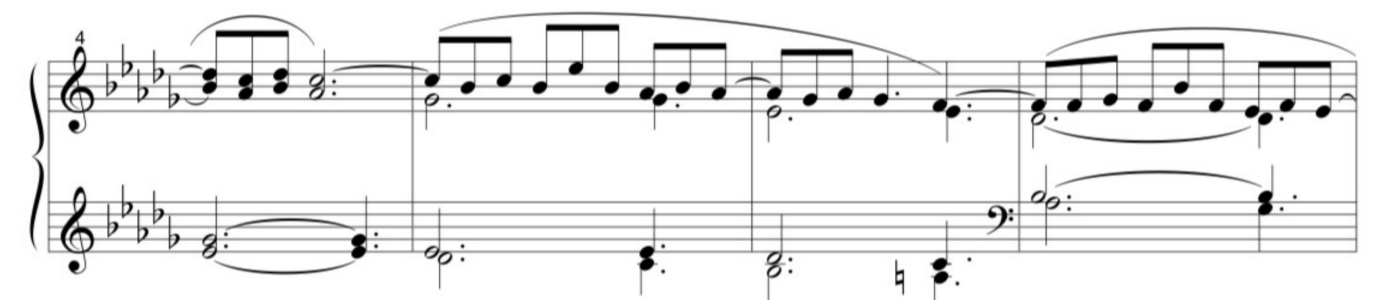




\section{Palavra-chave: economia}

Livro: Manifesto da noite (Colaboratório); recorte temporal: séc. XXI.

"Na economia mundial, não se faz mais diferença entre o dia e a noite" (COLABORATORIO,

2014, p. 41).

\section{Palavra-chave: entretenimento}

Livro: Manifesto da noite (Colaboratório); recorte temporal: séc. XXI.

O empresário paulistano Facundo Guerra diz que "São Paulo está começando a se dar conta de que o que a gente chama de noite pode ser chamado também de entretenimento, de serviço" (COLABORATÓRIO, 2014, p.51).

\section{Palavra-chave: liberdade}

Livro: O último herói (Rick Riordan); recorte temporal: séc. XX.

“... aquele tipo de música de acampamento que todo mundo tem vergonha de cantar no dia a dia mas que, à noite, com todos cantando juntos, vira uma brincadeira divertida" (RIORDAN, 2011, p. 100).

Livro: Manifesto da noite (Colaboratório); recorte temporal: séc. XXI.

"Não podemos mais fechar as portas da cidade ao anoitecer" (COLABORATORIO, 2014, p. 43).

Século XXI.

\section{Palavra-chave: luz da lua}

Livro: A Bíblia; recorte temporal: Idade Média.

"E fez Deus os dois grandes luminares: o luminar maior para governar o dia, e o luminar menor para governar a noite"(A BÍBLIA, Gênesis, cap 1 v.16, 2007).

\section{Sonata No. 14, 'Moonlight'}

\section{Adagio sostenuto}

Si deve suonare tutto questo pezzo delicatissimamente e senza sordini
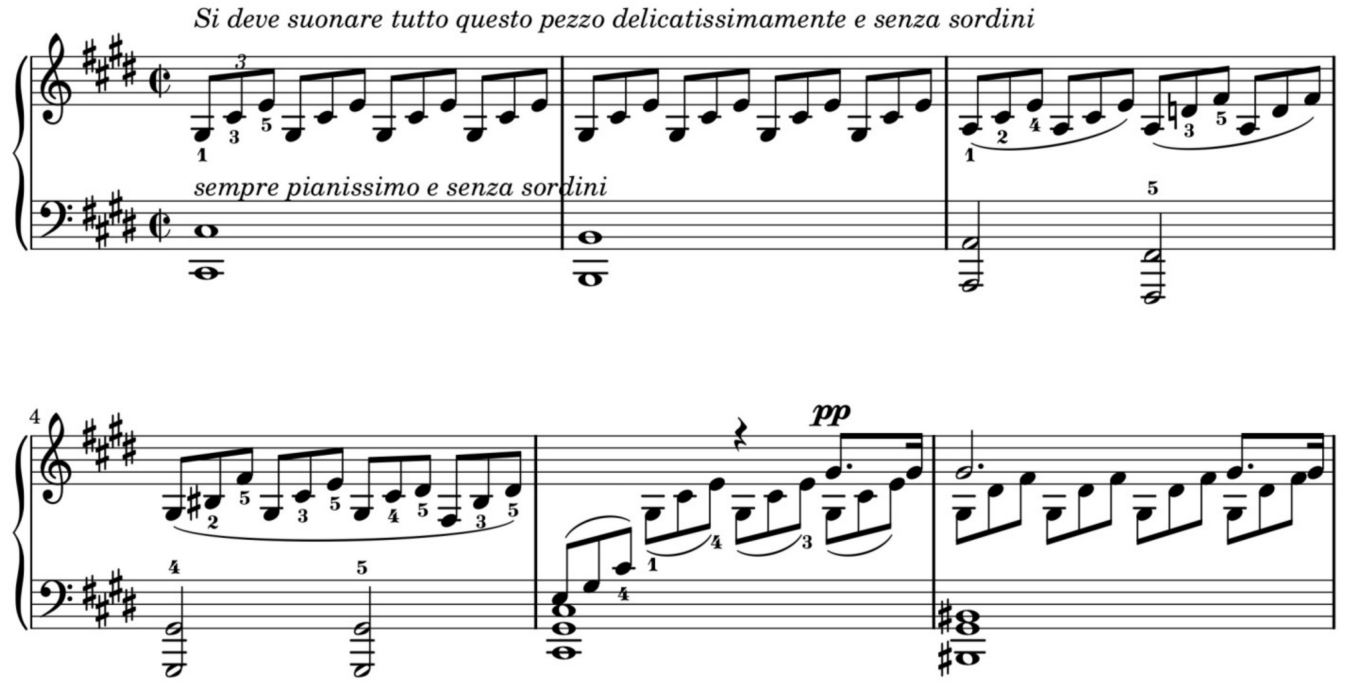

Figura 2

Partitura: Sonata n. 14, Moonlight (L. V. Beethoven) Fonte: arquivo pessoal. 
Figura 3

Pintura: An iron forge (Joseph

Wright, 1772).

Fonte: tate.org.uk.
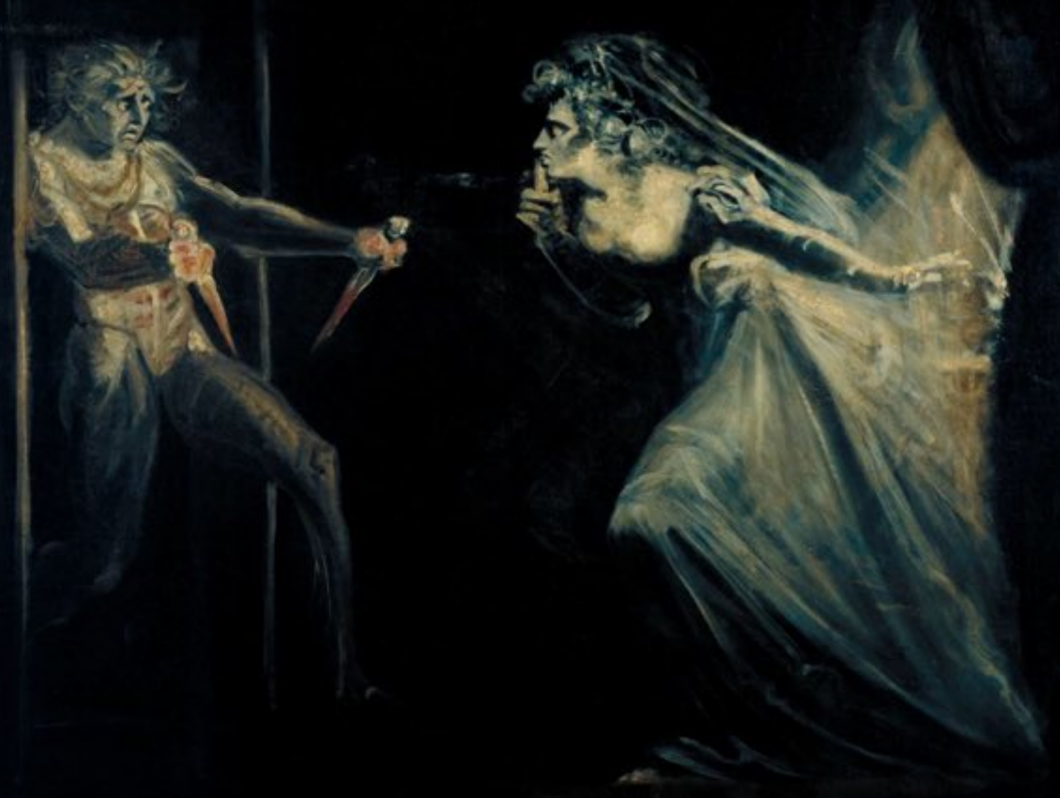

Figura 4

Pintura: Lady McBeth seizing the daggers (Henry Fuseli, exibido c. 1812).

Fonte: tate.org.uk. 
Livro: O viajante noturno (B. Traven); recorte temporal: séc. XIX até meados do séc. XX.

"O lugar se encheu de luz: era a lua iluminando meu quarto" (TRAVEN, 2008, p. 63).

\section{Palavra-chave: morte}

Livro: Escuridão total sem estrelas (Stephen King); recorte temporal: séc. XX.

"Sabia que seria uma má ideia transformar a bebida em um hábito, mas não é toda noite que um homem sente sua esposa morta tocar seu nariz" (KING, 2015, p. 52).

Livro: O céu é dos violentos (Flannery O’Connor); recorte temporal: séc. XX.

"Há duas noites que vejo o espírito dele", disse a mulher. "Foram duas noites seguidas que o vi e estava em desassossego (O'CONNOR, 2014, p. 41).

Livro: O viajante noturno (B. Traven); recorte temporal: séc. XIX até meados do séc. XX.

"O que é que você está me dizendo? Um índio morto - é sobre isso que você está me falando? Um índio morto que veio visitá-lo duas noites?" (TRAVEN, 2008, p. 73).

\section{Palavra-chave: escuridão/trevas}

Livro: A Bíblia; recorte temporal: Idade Média.

"E Deus chamou à luz Dia; e às trevas chamou Noite". (A BíBLIA, Gênesis, cap 1 v.5, 2007). Idade Média

Livro: O viajante noturno (B. Traven); recorte temporal: séc. XIX até meados do séc. XX.

"Macario voltou-se lentamente, foi até a porta e mergulhou na escuridão da noite" (TRAVEN 2008, p. 109). "Em toda a minha volta, não se via nenhuma luz, nem perto, nem longe, a não ser a luz das estrelas" (p. 80).

Livro: Escuridão total sem estrelas (Stephen King); recorte temporal: séc. XX.

...vi que eram 3h15 da manhã. Aproximei o relógio do ouvido para ver se ele ainda funcionava, mas também poderia ter confirmado a hora olhando pela janela para a escuridão sem lua lá fora (KING, 2015, p. 37).

\section{Palavra-chave: ritos}

Livro: A cidade antiga (Fustel de Coulanges); recorte temporal: Grécia e Roma Antigas.

"Entre os romanos, no dia Primeiro de Março cada família devia apagar o seu fogo sagrado e reacender logo outro em seu lugar" (COULANGES, 2005:19).

Livro: História do medo no Ocidente (Jean Delumeau); recorte temporal: séc XX.

"Com a chegada da noite, começa o velório" (DELUMEAU, 2009:135).

Livro: História noturna (Carl Ginsburg); recorte temporal: séculos XV, XVI e XVII.

"Bruxas e feiticeiros reuniam-se à noite, geralmente em lugares solitários, no campo ou na montanha" (GINZBURG, 2012:9).

Um passeio pela noite na música: cito por ora o Clair de lune (Debussy); Sonata ao Luar (Beethoven); Noite de paz (Franz Gruber); A noite do meu bem (Dolores Duran); A night in Tunisia (Dizzy Gillespie); Night and day (Cole Porter); Luar do sertão (Catulo da Paixão Cearense e João Pernambuco).

\section{Palavra-chave: luz da lua}

Partitura: Clair de lune (Claude Debussy, 1905); recorte temporal: séc. XX. (Figura 1)

Partitura: Sonata n. 14, Moonlight (L. V. Beethoven); recorte temporal: séc. XVIII. (Figura 2) 


\section{Um passeio pela noite na pintura}

Separei algumas pinturas em que podemos notar como a noite foi interpretada por diferentes pintores de diferentes épocas.

Palavra-chave: trabalho

Pintura: An iron forge (Joseph Wright, 1772); recorte temporal: séc. XVIII. Fonte: tate.org.uk (Figura 3)

Palavra-chave: luta

Pintura: Lady Macbeth Seizing the Daggers (Henry Fuseli, exibido c.1812); recorte temporal: séc. XIX. Fonte: tate.org.uk. (Figura 4)

Pintura: The field of Waterloo (William Turner, exibido em 1818); recorte temporal: séc. XIX. Fonte: tate.org.uk (Figura 5)

\section{Palavra-chave: mitos}

Pintura: The Ghost of a Flea (William Blake, c.1819-20); recorte temporal: séc. XIX. Fonte: tate.org.uk. (Figura 6)

Palavra-chave: contemplação

Pintura: Past and present n. 3 (August Leopold Egg, 1858); recorte temporal: séc. XIX. Fonte: tate.org.uk. (Figura 7)

Palavra-chave: iluminação artificial na cidade

Pintura: Boar Lane, Leeds (John Atkinson Grimshaw, 1881); recorte temporal: séc. XIX. Fonte: tate.org.uk. (Figura 8)

\section{Conclusão}

O pano de fundo das noites comparadas é a imaginação como território que nos conquista. Tal qual a noite escura, a imaginação é simulacro do invisível. No terreno do invisível a imaginação nos ensinou que demônios nos espreitam e sabem onde estamos. Mas no invisível também vivem aqueles que nos salvam. $O$ homem precisa de proteção. $\mathrm{E} a$ proteção vem de alguém (ou algo) que possui a iluminação. Alguém apto a nos dar segurança. Alguém maior e melhor do que aqueles dotados da mesma realidade que a nossa. $A$ invisibilidade produz a fé. $E$ no mundo natural, enquanto a noite derramou sua escuridão nas cidades ou nos quartos de dormir, era como se vendasse os olhos de cada um. E nós ficamos invisíveis para nós mesmos. Tal escuridão (invisibilidade) é a imaginação característica e capacidade psicológica humana. A imaginação quando convertida numa ideia que se repete e se populariza por diversos métodos de comunicá-la - a música, a pintura, a literatura, a arquitetura, a cidade - finda por se acumular na mente por outra capacidade psicológica humana: a memória. Uma memória repetida pode se converter numa realidade. Os produtores de modelos de imaginação em massa, como a igreja cristã medieval, criaram um tipo de realidade com a ideia de haver um paraíso à espera daqueles que aceitassem passar pelos ritos de depuração psicológica, portanto, comportamental. Nesse caso, trata-se da colonização da imaginação de modo a controlar este território emocional. Controla-se também a percepção do mundo à medida em que ideias de paraíso e inferno compõem uma realidade idealizada sobre mundo iluminado e mundo das trevas. Nesse ponto, a noite deixa de ser meramente um espaço visual (natural) para na prosa religiosa rimar com trevas, em que o mal é encenado por bruxas, num ambiente decorado por objetos "suspeitos" e até animais como o gato preto (que dá azar) e outras ideias dissipadas no imaginário oficializado pela igreja. 0 medo da noite será uma metástase no corpo das cidades.

A escuridão tornou-se ré. De sua quietude repousante no mundo natural se atribuíram-lhe também as ameaças contra as riquezas artificiais: o mundo monetário do ouro, das moedas, das quantificações arbitrárias; o mundo das ideologias; o mundo das invasões, das colonizações territoriais, inclusive o 
Figura 6

Pintura: The Ghost of a Flea

(William Blake, c. 1819-20).

Fonte: tate.org.uk.

Figura 7

Pintura: Past and present n. 3

(August Leopold Egg, 1858).

Fonte: tate.org.uk.

Figura 8

Pintura: Boar Lane Leeds (John

Atkinson Grimshaw, 1881).

Fonte: tate.org.uk. 
território do imaginário. Entretanto, as noites mais calmas ainda dormem nas montanhas, nos oceanos, fora das cidades ou em cidades menos atraentes por não possuírem grandes bancos, embora haja uma paróquia para lançar na população seus mitos e seus ritos em troca de proteção.

Inúmeros contrastes simbólicos surgem da heterogeneidade cultural, face à heterogeneidade emocional de se ter a noite como uma experiência estética, promovida pela gramática da escuridão que tanto oculta como revela.

\section{Referências}

A BÍBLIA. Tradução de João Ferreira Almeida. Rio de Janeiro: Edições Almeida Corrigida Fiel, 2007.3638 p. Velho Testamento e Novo Testamento. Ebook.

ALVAREZ, Alfred. Night: an exploration of night life, night language, sleep and dreams. London: J. Cape, 1994.

ARISTÓTELES. A política. $15^{\mathrm{a}}$ ed. Trad. Nestor Silveira Chaves. São Paulo: Editora Escala, sd.

BECKERT, Howard S. Truques da escrita: para começar e terminar teses, livros e artigos. Trad. Denise Bottmann. Rio de Janeiro: Jorge Zahar Editor, 2015.

COLABORATÓRIO. Manifesto da noite. São Paulo: Invisíveis Produções, 2014.

COULANGES, Fustel de. A cidade antiga. São Paulo: Ed. Rideel, 2005.

DELUMEAU, Jean. História do medo no Ocidente (13001800): uma cidade sitiada. Trad. Maria Lucia Machado. São Paulo: Companhia das Letras, 2009.

DICKENS, Charles. Vento noturno. Trad. Raul de Pollilo. São Paulo: Clube do livro, 1975.
FERREIRA, Aurélio Buarque de Holanda. Novo dicionário da língua portuguesa. 2. ed. Rio de Janeiro: Editora Nova Fronteira, 1986.

GINZBURG, Carlo. História noturna. Tradução: Nilson Moulin Louzada. São Paulo: Companhia de Bolso, 2012.

KING, Stephen. Escuridão total sem estrelas. Trad. Viviane Diniz. Rio de Janeiro: Objetiva, 2015. Formato Epub.

KOTHE, Flávio R. Arte comparada. Brasília: Editora Universidade de Brasília, 2016.

O'CONNOR, Flannery. O céu é dos violentos. Trad. Luís Coimbra. $1^{a}$. ed 1960. Lisboa: Relógio d'água editores, 2014.

RIORDAN, Rick. O herói perdido. Trad. Rodrigo Peixoto. Rio de Janeiro: Intrínseca, 2011.

RULFO, Juan. Pedro Páramo. Trad. Eric Nepomuceno. Rio de Janeiro: BestBolso, 2008.

SENNETT, Richard. Carne e pedra. Rio de Janeiro: BestBolso, 2008.

TRAVEN, B. O visitante noturno. Trad. Luciano Machado. São Paulo: Conrad Editora do Brasil, 2008.

TROTSKY (Temporada 1, ep. 3). Trotsky [Seriado]. Direção: Alexander Kott e Konstantin Statsky. Produção: Konstantin Ernst, Alexander Tsekalo, Maksim Polinskiy, Nikolai Bulygin, Aleksandra Remizova: Produtora: Sreda. Exibido originalmente pela TV Channel One, da Federação russa, 2017. color.

WILLIAMS, Reymond. O campo e a cidade: na história e na literatura. Trad. Paulo Henrique Britto. São Paulo: Companhia das Letras, 2011. 